\title{
Corporations and Human Life
}

\author{
Frank Partnoy ${ }^{*}$
}

CONTENTS

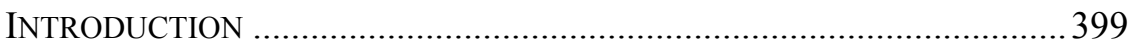

I. CORPORATE DECISION-MAKING AND HUMAN LIFE........................... 405

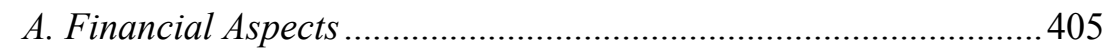

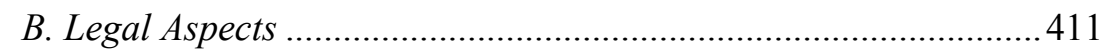

II. CORPORATE OVERSIGHT AND HUMAN LIFE....................................416

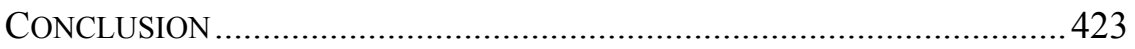

\section{INTRODUCTION}

Corporations kill people. ${ }^{1}$ Historically, social policy has responded to corporations that kill primarily through regulation and tort liability. Scholars have debated a range of questions related to these issues, including the challenges of assessing regulatory and tort liability costs in terms of human life. ${ }^{2}$

* I am grateful for comments from the participants in the Berle VIII Symposium, and also from Laura Adams, Anat Admati, Jordan Barry, Michael Brennan, Robert Daines, Vic Fleischer, Dov Fox, Kent Greenfield, Colleen Honigsberg, Robert Jackson, Michael Klausner, Orly Lobel, Shaun Martin, Justin McCrary, Mitchell Polinsky, Myron Scholes, Mila Sohoni, Steven Davidoff Solomon, George Triantis, and Samuel Weinstein. I thank Abbigale Cook for her excellent work as a research assistant.

1. Although there are difficult questions about whether to attribute deaths to corporations as opposed to individuals associated with those corporations, there is no doubt that substantial numbers of human lives are lost as a result of corporate activity and decisions. More Americans die from unhealthy or unsafe workplace conditions than from homicides. See JefFrey H. ReIman, The Rich Get Richer; THE POOR Get PRISON: IDEOLOGY, ClASS, AND CRIMINAL JuSTiCE (Jeffrey Reiman \& Paul Leighton eds., 10th ed. 2016). The numbers are particularly striking if one includes nonprofit corporations, such as hospitals; medical error is estimated to be the third largest cause of death in the United States. See Martin A. Makary \& Michael Daniel, Medical Error: The Third Leading Cause of Death in the US, 353 BMJ i2139 (2016).

2. See, e.g., Matthew D. Adler, Well-Being and Fair Distribution: Beyond COST-BENEFIT ANALYSIS (2012) (critiquing the economic efficiency rationale of cost-benefit analysis and considering alternative approaches to the analysis of well-being); Richard Thaler \& Sherwin Rosen, The Value of Saving a Life: Evidence from the Labor Market, in HousEHOLD 
In this Article, I explore the role corporate law and governance might play in this area. For example, consider a corporate decision that will generate $\$ 5$ million of profit today but will result in the loss of one human life in ten years. Both regulation and tort liability might attempt to affect such a decision, but they are external approaches by government, not internal approaches by corporations. ${ }^{3}$

My focus here is on the relationship between corporate law and governance and the effects of two aspects of corporate behavior - decision-making and oversight ${ }^{4}$ —on human life. I examine this relationship, not from the outside perspective of regulators, legislators, and judges, but from the inside perspective of corporate actors themselves. The central question is this: how should corporate law and governance address tradeoffs between corporate profits and human life?

The above example - trading off corporate profits today for human lives lost tomorrow-is not merely abstract. Consider cars. For decades, car manufacturers have made decisions that traded off profits against risk to human life. During the 1970 s, Ford conducted cost-benefit analyses related to the risks associated with the Pinto, a car that presented a serious fire hazard when struck from the rear, even in low-speed collisions. ${ }^{5}$ More recently, it was revealed that some car manufacturers decided during the 1990s to use an airbag that was a few dollars cheaper but posed known risks from a dangerous and volatile chemical in its inflator; at least fourteen people have been killed by that inflator. ${ }^{6}$

Production AND CONSUMPTION 412-42 (Nestor E. Terleckyj, ed. 1976) (estimating the value of human life based on individuals' marginal valuations of safety); Frank Ackerman \& Lisa Heinzerling, Pricing the Priceless: Cost-Benefit of Environmental Protection, 150 U. PA. L. REV. 1553 (2002) (critiquing cost-benefit analysis in the environmental context); Eric A. Posner \& Cass R. Sunstein, Dollars and Death, 72 U. CHI L. REV. 537 (2005) (discussing how the legal system should address the cost of human life).

3. Corporations might influence government, and vice versa, but such influence is incident to the regulatory and tort regimes, not necessarily part of modern corporate law and governance.

4. Many corporate law academics and practitioners divide the analysis of corporate law into two separate concepts: board decision-making and oversight. See ALAN R. PALMITER \& FRANK PARTNOY, CORPORATIONS: A CONTEMPORARY APPROACH, chs. 18-19 (2d ed. 2014) (including separate chapters for board decision-making and board oversight).

5. A Ford internal report, Fatalities Associated with Crash-Induced Fuel Leakage and Fires, had recommended against safety improvements, which Ford estimated would cost $\$ 11$ per vehicle but generate safety benefits of only $\$ 5$ to $\$ 8$ per vehicle. See WiLliam H. SHAW \& VincENT E. BarRY, MORAL ISSUES IN BUSINESS 83-86 (8th ed. 2001). At the time, the National Highway Traffic Safety Administration had estimated that society lost $\$ 200,725$ every time a person was killed in an auto accident. This estimate included future productivity losses of $\$ 173,300$, victim's pain and suffering of $\$ 10,000$, and other costs. See id.

6. See Hiroko Tabuchi, The Quest to Save a Few Dollars Per Airbag Led to a Deadly Crisis, N.Y. TIMES (Aug. 27, 2016), http://www.nytimes.com/2016/08/27/business/takata-airbag-recallcrisis.html. 
Autonomous, or self-driving, cars in particular raise new, perhaps intractable, questions about profit-life tradeoffs. For example, the designers of autonomous car algorithms might program cars faced with dangerous situations to respond in ways that protect their passengers even when those responses endanger the lives of pedestrians or people in other cars. Not surprisingly, potential consumers say they prefer to protect their own lives and the lives of those traveling with them versus the lives of others who might be killed by their autonomous cars. ${ }^{7}$ Regulation and tort liability might address the extent to which autonomous car algorithms may protect passengers versus pedestrians. But corporations that produce such cars inevitably will make profit-life tradeoffs, and they likely will do so before any regulatory, legislative, or judicial reaction. ${ }^{8}$

Pharmaceutical and medical device corporations face similar dilemmas. Some appear to embrace principles that go beyond cost-benefit analysis related to regulation and tort liability. For example, some pharmaceutical corporations say they are openly committed to enhancing and saving lives and accordingly will not allow their products to be used in lethal injections. ${ }^{9}$ Such corporations also trade off improvements to human life today versus risks to life in the future.

Or consider consumer products corporations. Some, such as Chick-fil-A, explicitly claim to embrace human life. ${ }^{10}$ Others, like IKEA, are less explicit but have a mission to improve human lives. ${ }^{11}$ Some corporations that sell unhealthy foods, such as Ben and Jerry's and In-N-Out Burger, emphasize prohealth policies, even as their businesses arguably contribute to obesity and health problems that increase the risk

7. See Jean-Francois Bonnefon, Azim Shariff \& Iyad Rahwan, The Social Dilemma of Autonomous Vehicles, 352 SCIENCE 1573 (2016).

8. For a general discussion of legal issues related to autonomous cars, see Jordan M. Barry \& Elizabeth Pollman, Regulatory Entrepreneurship, 90 S. CAL. L. REV. (forthcoming 2017).

9. See Industry Statements and Action on Execution Drugs, REPRIEVE (July 8, 2016, 5:43 PM), http://www.reprieve.org.uk/case-study/manufacturer-action-on-execution-drugs/

[https://perma.cc/55N6-9NVL]; PFIZER's POSITION ON USE OF OUR PRODUCTS IN LETHAL Injections for Capital Punishment, Pfizer Pharmaceutical, http://www.pfizer.com/files/ b2b/GlobalPolicyPaperLethalInjection.pdf [https://perma.cc/7R9T-DJVS].

10. Chick-fil-A, a fast-food chain, has publicly stated that its "Corporate Purpose is ' $[\mathrm{t}] \mathrm{o}$ glorify God by being a faithful steward of all that is entrusted to us and to have a positive influence on all who come into contact with Chick-fil-A." See Corporate Responsibility, CHICK-FIL-A, http://www.chick-fil-a.com/Company/Responsibility-Giving-Tradition [https://perma.cc/9QDTW3GH]; see also Sustainability, CHICK-FIL-A, http://www.chick-fil-a.com/Company/Environmental [https://perma.cc/TE74-5XH6] (describing Chick-Fil-A's efforts to enrich and improve people's lives). Chick-fil-A has funded a pro-life pregnancy service organization, though it is regarded as remaining neutral on the issue of life generally. See Chick-Fil-A, 2NDVotE (2015), https://www.2ndvote.com/scores/chick_fil_a [https://perma.cc/ZU7M-EG2D] (“Chick-fil-A remains neutral on the issue of life.").

11. IKEA, the home furnishing company, states a goal "[t]o create a better everyday life for the many people.” IKEA, http://www.ikea.com. Ikea also favors sustainable growth. Id. 
of death. ${ }^{12}$ How should consumer products corporations assess the risk that their products pose to human life? Or take one recent challenge faced by IKEA: on June 28, 2016, IKEA issued a voluntary recall for about 29 million chests and dressers after six children-all under the age of four-were killed and at least thirty-six others were injured in the United States. ${ }^{13}$ Regulation and tort liability already address problems like IKEA's. Might corporate law and governance also play a role?

These corporations' decisions and oversight efforts are governed by articles of incorporation, bylaws, and corporate statutes that typically do not explicitly address human life. In this Article, I want to raise the question about whether they should.

My query about life is relevant to several literatures about the role of the corporation in society. For example, several scholars recently have raised a number of intriguing questions about corporate personhood. Should the concept of corporate personhood be limited to protecting the rights of the involved human shareholders? ${ }^{14}$ Under what circumstances and bases should corporations be criminally liable? ${ }^{15}$ To what extent does the corporate form serve intergenerational efficiency by encouraging decisions that benefit future human generations? ${ }^{16}$ How does the concept of limited liability relate to the distinctions between corporate and human

12. See Ben \& JeRrY's Homemade ICE CREAM, http://www.benjerry.com; Catherine Taibi, 9 Reasons to Love Ben \& Jerry's that Have Nothing to Do with Ice Cream, HufFInGTON Post (Aug. 15, 2013, 2:22 PM), http://www.huffingtonpost.com/2013/08/15/ben-and-jerryslove_n_3726083.html [https://perma.cc/2CHB-PH33]; In-N-Out Burger Nutrition Facts, IN-N-OuT (2010), http://www.inn-out.com/pdf/nutrition_2010.pdf [https://perma.cc/F4TE-TNTL]. Ben and Jerry's even produced a documentary film on obesity. See OBESITY: THE WORLDWIDE KILLER (Ben \& Jerry's Production 2016). Similarly, tobacco corporations and banks have corporate social responsibility campaigns aimed at saving and improving lives, in part to counter the negative perceptions arising from their activities. See Frank Partnoy \& Jesse Eisinger, What's Inside America's Banks, ATLANTIC (Jan./Feb. 2013), http://www.theatlantic.com/magazine/archive/2013/01/whats-inside-americas-banks/309196/ [https://perma.cc/VL27-9P9C] (describing both Wells Fargo's risks and its social responsibility efforts).

13. The injuries and deaths had occurred since 1989. See Mike McPhate, Ikea Recalls 29 Million Chests and Dressers After 6 Children Die, N.Y. TIMES (June 28, 2016), http://www.nytimes.com/ 2016/06/29/business/ikea-recall-tip-over-furniture.html?_r=0; see also Ikea Corporate News, IKEA (June 28, 2016), http://www.ikea.com/us/en/about_ikea/newsitem/062816-pr-chest-and-dressers [https://perma.cc/9XVM-JZBA].

14. See Kent H. Greenfield, In Defense of Corporate Persons, 30 Const. Comm. 309 (2015); Elizabeth Pollman, Reconceiving Corporate Personhood, 2011 UTAH L. REV. 1629, 1630 (2012).

15. See William S. Laufer, Corporate Bodies and Guilty Minds: The Failure of CORPORATE CRIMINAL LIABILITY 11-12 (2008).

16. See Lynn A. Stout, Presentation at the University of Chicago Law School Law and Economics Workshop: The Corporation and The Question of Time 3-5 (Oct. 20, 2015), http://www.law.uchicago.edu/files/file/stout_with_cover_qoftime.pdf [https://perma.cc/B2DG4 SQF]; Lynn A. Stout, The Corporation as Time Machine: Intergenerational Equity, Intergenerational Efficiency, and the Corporate Form, 38 SEATTLE U. L. REV. 685, 686 (2015). 
personhood ${ }^{17}$ This Article seeks to add one profound question to this expanding new list. If corporations really are "people," how should we think about them when they kill?

Questions about corporations and human life also are central in the debate about whether corporations are too focused on the short-term. For example, some recent research suggests that the discount rates used by corporate managers to assess future projects are increasing. ${ }^{18}$ Increasing discount rates could lead to corporations valuing future human lives less. Just as the climate change literature has addressed the potential problems of using high discount rates to assess future costs, the corporate law literature might address the potential problems of using high discount rates to assess risk to human life.

The point of this Article is not to answer any of these questions in any comprehensive or definitive way, but to suggest some preliminary answers and some areas of new research. One can conceptualize this new area of inquiry as "tragic choices" applied to the corporate context (as opposed to the governmental and regulatory context in which Guido Calabresi and Philip Bobbitt first explored the "tragic choices" notion). ${ }^{19}$ Corporate decision-making and oversight that impacts human life will become increasingly "tragic" if corporate discount rates rise, and therefore the present value of future costs - including human life - declines.

This Article will examine these questions in the context of corporate decision-making and oversight. First, in Part I, I address decision-making. How should risk to human life be included in the jurisprudence of corporate decision-making? In terms of finance, how should corporations make net present value decisions when risk to human life is a factor? In terms of law, is there a case for exceptions to the business judgment rule based on risk to human life?

Second, in Part II, I address oversight. How should risk to human life be included in the jurisprudence of oversight? In terms of finance, how

17. Adam Winkler has noted that although it was the corporate person, not the shareholders of Hobby Lobby, who was required by law to provide birth control, the shareholders nevertheless sought judicial validation of their personal beliefs about birth control, even as they retained the corporate form's protection of limited liability. See Adam Winkler, Yes, Corporations Are People Too, SLATE (Mar. 17, 2014), http://www.slate.com/articles/news_and_politics/jurisprudence/2014/03/ corporations_are_people_and that_s_why_hobby_lobby_should_lose_at the_supreme.html [https://perma.cc/G9ZX-EUAH].

18. See Rachelle C. Sampson \& Yuan Shi, Evidence and Implications of Short-termism in US Public Capital Markets: 1980-2013 (July 27, 2016) (unpublished manuscript), https://papers.ssrn.com/sol3/papers.cfm?abstract_id=2837524 (finding increasing discount rates and increasing short-termism during the previous thirty years).

19. See Guido Calabresi \& Philip BobBitt, Tragic Choices (1978). In the context of this Article, it is private corporations, not public regulators, legislators, and judges that are making decisions and engaging in decisions and oversight in ways that can present tragic choices with respect to human lives. 
should corporations approach risk management when human life is a factor? In terms of law, is there a case for different treatment of corporate oversight of risk to human life? ${ }^{20}$

My tentative answer is that corporate boards should explicitly address risk to human life in both decisions and oversight, and judges in corporate law cases should apply a heightened standard of scrutiny in cases when boards have not done so. In addition, with respect to corporate decisions and oversight related to risks to human life, policy makers should consider moving away from the traditional external governance associated with regulation and tort liability in favor of internal corporate governance.

One way to encourage such movement would be new "shield laws" that protect the details of corporate decision-making and oversight with respect to risk to human life from scrutiny by regulators and tort litigants. Such laws might encourage corporate actors who are currently unwilling to consider risks to human life explicitly (because of concerns about regulation and tort liability) to develop a framework for considering those risks. The challenge associated with such laws would be maintaining appropriate incentives for corporate actors to take care to avoid loss of human life, while encouraging them to consider more precisely the effects of their decisions and oversight.

Some of these efforts would require changes to the way corporations are governed under state and federal law. Groups that advocate on behalf of benefit corporations might lead the way, perhaps starting with a more limited approach. For example, a state benefit corporation statute could be amended to provide for exculpation of directors for breaches of fiduciary duty that result in the loss of human life only if the board previously had "reasonably considered potential risks to human life." Alternatively, benefit corporations could adopt new charters and bylaws that explicitly address risk to human life. A new default rule encouraging such provisions might lead boards to address questions about such risks more explicitly, or at least encourage a culture of addressing such risks within the corporation. $^{21}$

The Berle VIII Symposium focused on the idea that the corporation has been or can be a device for making long-term "firm commitments" with respect to a range of issues beyond shareholder wealth

20. See In re Caremark International Inc. Derivative Litigation, 698 A.2d 959 (Del. Ch. 1996) (addressing corporate director oversight).

21. See Richard H. Thaler \& Cass R. Sunstein, Nudge: Improving Decisions About HEALTH, WEALTH, AND HAPPINESS (2008). 
maximization. ${ }^{22}$ This Article suggests one specific area in which corporations might make just such a firm commitment: risk to human life. In a just society, human persons undertake efforts to ensure that their actions do not kill others. Corporate persons should do the same.

\section{CORPORATE DECISION-MAKING AND HUMAN LIFE}

I begin by returning to the example I set out at the beginning of this Article: a corporate decision that will generate $\$ 5$ million of profit today but will result in the loss of one human life in ten years. Such a decision has financial and legal aspects, both of which raise interesting issues. I assess the financial aspects of such a corporate decision first and then turn to the relevant corporate law challenges.

\section{A. Financial Aspects}

From a financial perspective, one standard concept that might ${ }^{23}$ be used to assess the above example is net present value, or NPV. NPV is the difference between the present value of the cash inflows and outflows associated with a project or decision. The basic idea of the NPV rule in finance is that corporations should only engage in a project if it has $\mathrm{NPV}>0 .{ }^{24}$ In this example, that NPV rule calculus is equivalent to asking whether $\$ 5$ million (the positive present inflow) is greater than the absolute value in today's terms of the loss of one human life in ten years (the negative future outflow). In that event, the net present value of the present inflow and the future outflow would be positive, the project would have positive NPV, and the NPV decision rule would say that the corporation

22. See Colin MAYER, Firm COMMITMENT: Why THE CORPORATION IS FAILING US AND How TO RESTORE TRUST IN IT (2013).

23. I say "might" because some scholars reject the notion that discount rates or NPV calculations should be used when considering the impact of decisions on future persons and generations. See Michael Klausner, When Time Isn't Money: Foundation Payments and the Time Value of Money, 1 StAN. SOC. InNOVATION REV. 51 (2003) (arguing that discounted cash flow analysis should not be applied to the analysis of grants by charitable foundations). Klausner argues that although there are some justifications for favoring current charity over future charity, including cost-effectiveness, future expectations about economic growth, and intergenerational equity, discounting is a flawed approach that privileges current generations over future generations with no ethical or economic basis. Id. at 59 . Klausner is not alone: the philosopher John Rawls and the economist Frank Ramsey similarly argued against discounting future generations merely because of timing. See JOHN RAWLS, A THEORY OF JUSTICE 294 (1971) (concluding that "the different temporal positions of persons and generations does not in itself justify treating them differently"); Frank Ramsey, A Mathematical Theory of Saving, 38 ECON. J. 543 (Dec. 1928) (taking the position that discounting future generations was ethically indefensible).

24. See Captial Budgeting Valuation: Financial Analysis for Today's InVestment ProjeCts 61 (H. Kent Baker \& Philip English eds., 2011). 
should do the project; otherwise, if the present value of the future outflow is too high, it should not. ${ }^{25}$

Calculating the present value of the loss of one human life in ten years requires two steps. First, one must assess the value of a human life. Second, one must discount that value to today. ${ }^{26}$

There is extensive, and controversial, literature in economics devoted to assessing the value of human life, ${ }^{27}$ and many scholars find it objectionable. ${ }^{28}$ Nevertheless, current regulatory and tort approaches require such estimates. ${ }^{29}$ Indeed, regulatory agencies have been required to engage in cost-benefit analysis since $1981,{ }^{30}$ and tort liability statutes have long provided for damages for wrongful death. ${ }^{31}$ Some scholars have criticized such approaches as unpredictable. ${ }^{32}$ Nevertheless, they continue.

The value of a statistical life can be estimated in two ways. First, researchers survey people and ask them "stated preferences" questions that indicate how much they value a life. ${ }^{33}$ Second, researchers calculate "revealed preferences" based on data regarding people's decisions to engage in risky activities. Examples of "revealed preferences" include differences in wages for jobs (e.g., coal mining) that have relatively high pay but also higher risks, or differences in traffic fatalities given increased risk, such as driving conditions, distances, and speeds. ${ }^{34}$ Both approaches

25. Note that in practice, the facts typically will not be as clear as they are in this hypothetical. Indeed, corporate decision-makers might argue they thought that decisions would not result in the loss of human life or that risk to human life was very low. Indeed, as noted above, given the experience of corporate actors in previous cases, such as the Ford Pinto, corporate directors and officers likely would try to avoid being as precise as this hypothetical is in their risk assessment. Nevertheless, the example is a useful starting point.

26. As noted above, some scholars reject the notion that such discounting is even possible, in part because dollars and human lives, or human lives today and human lives in the future, are not fungible. See Klausner, supra note 23.

27. See W. Kip Viscusi \& Joseph E. Aldy, The Value of a Statistical Life: A Critical Review of Market Estimates Throughout the World, 27 J. RISK \& UNCERTAINTY 5 (2003) (reviewing a range of valuation approaches).

28. See Frank Ackerman \& Lisa Heinzerling, Pricing the Priceless, 150 U. PA. L. REV. 1553, 1556 (describing cost-benefit analysis as inherently flawed and absurd).

29. See Posner and Sunstein, supra note 2, at 549-52 (evaluating regulatory assessments of the value of human life).

30. See Exec. Order No. 12291, 46 Fed. Reg. 13,193 (Feb. 17, 1981) (requiring cost-benefit analysis).

31. See Posner \& Sunstein, supra note 2, at 543-49.

32. See Matthew D. Adler \& Eric A. Posner, Implementing Cost-Benefit Analysis When Preferences Are Distorted, 29 J. Legal STUD. 1105, 1142-46 (2000).

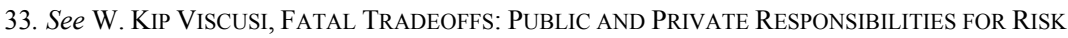
(1992).

34. For example, in 1987, the federal government gave states the opportunity to choose a speed limit for rural interstate highways that was higher than the uniform national maximum speed limit; most states with rural interstate highways adopted $65 \mathrm{mph}$ speed limits, while a few retained $55 \mathrm{mph}$ speed limits. These differences enabled researchers to test drivers' apparent tradeoffs between speed and risk, based on the assumption that driving faster saved time and made people better off. See Orley 
are based on the idea that people will accept some increase in the probability of death in exchange for an increase in well-being or wealth.

In other words, researchers assume that the change in wealth required to engage in a risky activity is roughly equal to the increased probability of death from the activity multiplied by the value of life. (Equivalently, the value of life is assumed to be roughly equal to the change in wealth divided by the change in the probability of death.) Thus, stated preferences studies ask subjects how much of an increase in wealth they would require to engage in a risky activity, and revealed preferences studies examine how much of an increase in wealth people actually require. ${ }^{35}$ Both approaches result in a range of value estimates of human life.

How much is one human life worth? Regulatory cost-benefit analysis and tort liability reflect widely ranging estimates of that value, from a few hundred thousand dollars to tens of millions of dollars. Depending on the area and assumptions, mean and median valuations are in the range of $\$ 9-\$ 10$ million per life. ${ }^{36}$ Alternatively, some policy makers frame the analysis in terms of quality-adjusted life years, or QALYs, to try to avoid some of the difficulties associated with differences in life expectancies and life quality. Studies suggest ranges broadly consistent with estimates of the value of a human life. ${ }^{37}$ Scholars have sought to expand this analysis to consider quality of life, well-being, and other issues. ${ }^{38}$ Nevertheless, one rough estimate of the value of one human that corporations might use, at least as of today, is $\$ 10$ million.

Corporate agents who seek to calculate the value of a human life in assessing a decision might rely on some or all of the estimates and calculations previously discussed, or they might choose to engage in their own study. In order to make an NPV calculation, corporate managers would need at least an expected value based on the risks and uncertainties. The NPV calculation, like regulatory cost-benefit analysis and tort damages, requires a number. Moreover, even corporate managers who

Ashenfelter, Measuring the Value of a Statistical Life: Problems and Prospects, 16-22 (IZA, Working Paper No. 1911, 2006).

35. William Shulze et al., Economic Valuation of Mortality Risk Reduction 17 (2004), https://yosemite.epa.gov/ee/epa/eerm.nsf/vwAN/EE-0488-01.pdf/\$file/EE-0488-01.pdf [https://perma.cc/RT8S-8VYW].

36. For example, some recent estimates were $\$ 9.7$ million by the Environment Protection Agency in 2013, $\$ 9.4$ million by the Department of Transportation in 2014, and $\$ 9.3$ million by the Food and Drug Administration in 2015. See Jo Craven McGinty, Why the Government Puts a Dollar Value on Life, WALL ST. J. (Mar. 25, 2016, 9:08 AM), http://www.wsj.com/articles/why-the-government-putsa-dollar-value-on-life-1458911310 [https://perma.cc/HM53-6LFD].

37. See Linda Ryen \& Mikael Svensson, The Willingness to Pay for a Quality Adjusted Life Year: A Review of the Empirical Literature, 24 HEALth ECON. 1289 (2015); Matthew Hutson, Calculating the Value of Life, NEw YORKER (Oct. 4, 2013), http://www.newyorker.com/ tech/elements/calculating-the-value-of-a-life [https://perma.cc/7SX3-GEQ7].

38. See ADLER, supra note 2. 
make decisions based on analyses other than NPV might nevertheless understand that other methodologies value a statistical human life in the range of $\$ 10$ million.

After one has determined the value of a human life in dollar terms, the second step is to estimate the time at which that negative cost is likely to be incurred ${ }^{39}$ and then discount the amount to today's present value using a discount rate. It is likely to be difficult for corporations to estimate precisely how many human lives a decision is likely to affect and when those people are likely to die. Nevertheless, corporate actors are not entirely ignorant of the relevant factors that put human life at risk and are likely to be in the best position, from an informational perspective, to assess risk to human life. My remaining analysis here is focused, not on the timing and magnitude of individual corporate calculations about the human life cost of particular decisions, but on the more general question about which discount rate should apply once a corporation has made such calculations.

Which discount rate will a corporation use in the above example? A corporation might use its own estimate of its weighted-average cost of capital; there is literature on how to choose that number and a consensus that corporations generally should choose a discount rate for a project that reflects the risk associated with that project. ${ }^{40}$ However, in practice, corporations do not always use discount rates that accurately reflect the risk of a project. A large, conservative company might use a relatively low cost of capital that is close to the risk-free or government rate. A start-up company might use a significantly higher cost of capital, consistent with the venture capital ranges described above. ${ }^{41}$ In general, a company interested in accurately discounting the loss of one human life in ten years could use a discount rate comparable to that associated with a matching life insurance policy, which would reflect the market assessment of the loss of life. However, there are no strict legal constraints on a corporation's choice of discount rate.

The result of a corporation's choice of discount rate can be dramatic, and even dispositive. In the above example, if Company A used a 1\%

39. In this example, I have assumed that the human life cost will be incurred in ten years. In practice, estimating the timing of such a cost will be difficult and likely would involve a range of estimates, perhaps with a specified mean and statistical distribution. For example, one might determine that on average one life would be lost in ten years, and that the distribution around that time would be a normal distribution with a standard deviation of two years. Such actuarial assumptions can be challenging, but are common in certain industries, particularly life insurance.

40. See Michael T. Jacobs \& Anil Shivdasani, Do You Know Your Cost of Capital?, HaRv. Bus. REV., July-Aug. 2012, https://hbr.org/2012/07/do-you-know-your-cost-of-capital [https://perma.cc/ LAP9-ZGCZ].

41. See Sanjai Bhagat, Why Do Venture Capitalists Use Such High Discount Rates?, 15 J. RisK FIN. 94, 94 (2014). 
annual discount rate, it would calculate the present value of a $\$ 10$ million negative cash flow in ten years as being approximately $\$ 9.1$ million. Alternatively, if Company B used a 30\% annual discount rate, it would calculate the present value of the same cash flow as being approximately $\$ 725,000$. As a result, Company A would determine that the project had a negative NPV ( $\$ 5$ million minus $\$ 9.1$ million), whereas Company B would determine that the project had a positive NPV ( $\$ 5$ million minus $\$ 725,000)$. Company A would reject the project; Company B would accept it.

Discount rates for corporate NPV calculations can be significantly higher than those used for regulatory or tort liability purposes. Discount rates for public corporations can be estimated based on market prices of corporate bonds or loans, and are typically well above government bond yields; discount rates for private corporations can be even higher. For example, venture capitalists typically use discount rates in the range of $30 \%-70 \%$, and discount rates during the start-up stage of venture capital investments are commonly between $50 \%-70 \%{ }^{42}$ Moreover, analysts valuing private businesses use higher discount rates to reflect skepticism about future cash flows, as well as higher expected bankruptcy costs. ${ }^{43}$ Using such high rates would lead corporations to conclude that future human lives are worth relatively little in present value terms.

Numerous scholars have considered questions about the choice of discount rates and social policy. Although the most recent debate relates to the climate change literature, the debate generally extends back for decades. Kenneth Arrow considered optimal discounting in the context of public investment criteria. ${ }^{44}$ William Baumol suggested that taxes and risk made optimal discount rates indeterminate. ${ }^{45}$ Amartya Sen and Gordon Tullock debated the parameters that were relevant to determining social discount rates as opposed to private discount rates. ${ }^{46}$ Later, during the 1990s, several legal scholars debated the role of discount rates in various

42. See id.

43. Aswath Damodaran, Valuing Young, Start-up and Growth Companies: Estimation Issues and Valuation Challenges, (May 14, 2009) (unpublished manuscript) http://people.stern.nyu.edu/ adamodar/pdfiles/papers/younggrowth.pdf.

44. See Kenneth J. Arrow, Discounting and Public Investment Criteria, in WATER ReSEARCH: ECONOMiC ANAlysis, Water Management, Evaluation Problems, Water Reallocation, Political and Administrative Problems, Hydrology and Engineering, Research Programs AND NEEDS 13 (Allen V. Kneese and Stephen C. Smith eds., 1966).

45. See William J. Baumol, On the Social Rate of Discount, 58 AM. ECON. REV. 788 (1968).

46. See Amartya K. Sen, Isolation, Assurance and the Social Discount Rate, 81 Q.J. EcON. 112 (1967); Gordon Tullock, The Social Rate of Discount and the Optimal Rate of Investment: Comment, 78 Q.J. ECON. 331 (1964). 
contexts. ${ }^{47}$ Likewise, discounting models have recently occupied the finance literature..$^{48}$ Regulatory cost-benefit analysis and tort liability also reflect widely ranging estimates of the applicable discount rate, which often is set by rule or statute. ${ }^{49}$

One rationale for the choice of a discount rate for some regulatory purposes is that the government borrowing rate is appropriate, given that the project is being undertaken by a government entity. ${ }^{50}$ Other scholars have argued that for many future costs, such as the costs of climate change, a government borrowing discount rate is too high. ${ }^{51}$

For example, for certain purposes, the Office of Management and Budget uses a discount rate of 7\%; other government discount rates are lower. ${ }^{52}$ At a $7 \%$ discount rate, the present value today of the cost of a human life lost in one year might be estimated as $\$ 10$ million divided by 1.07 , or approximately $\$ 9.35$ million. ${ }^{53}$ The present value today of the cost of a human life lost in 10 years would be $\$ 10$ million divided by $1.07^{10}$, or approximately $\$ 5.1$ million. The present value today of the cost of a human life lost in 100 years would be $\$ 10$ million divided by $1.07^{100}$, or approximately $\$ 11,500$. In contrast, the present values for 1,10 , and 100 years of a $\$ 10$ million loss at a $1 \%$ discount rate would be approximately $\$ 9.9$ million, \$9.1 million, and $\$ 3.7$ million, respectively, whereas the present values for 1,10 , and 100 years of a $\$ 10$ million loss at a $30 \%$ discount rate would be approximately $\$ 7.7$ million, $\$ 725,000$, and $\$ 0.00$, respectively.

47. See Daniel A. Farber \& Paul A. Hemmersbaugh, The Shadow of the Future: Discount Rates, Later Generations, and the Environment, 46 VAND. L. REV. 267 (1993); Cass R. Sunstein \& Arden Rowell, On Discounting Regulatory Benefits: Risk, Money, and Intergenerational Equity, 74 U. CHI. L. Rev. 171 (2007); Richard L. Revesz, Environmental Regulation, Cost-Benefit Analysis, and the Discounting of Human Lives, 99 COLUM. L. ReV. 941 (1999).

48. See Frank Partnoy, WAIT: The ART AND SCIENCE of Delay (2012).

49. See, e.g., J.F.P. Offshore, Inc. v. Diamond, 600 So. 2d 1002 (Ala. 1992) (requiring a court to instruct the jury on the below-market discount rate method, limiting the economic damages expert's choice of methods/rates); GA. CODE ANN. §51-12-13 (2013) (establishing a 5\% minimum in civil liability); JUD. COUNCIL OF CAL. CiV. JURY INSTRUCTIONS § 3904B (requiring that damages be awarded at present value, but not dictating a rate); OFFICE OF MGMT \& BUDGET, EXEC. OFFICE OF THE President, OMB , Circular No. A-94 Revised, Guidelines AND Discount RATES For BENEFiTCOST ANALYSIS OF FEDERAL PROGRAMS (1992), https://www.whitehouse.gov/omb/circulars_a094 [https://perma.cc/E9SK-DF9L].

50. See Arrow, supra note 44.

51. See PARTNOY, supra note 48.

52. See id.; Office of Mgmt \& Budget, Exec. Office of the President, OMB Circular No. A-94 Appendix C, Discount Rates For Cost-EFFectiveness, Lease Purchase, AND RELATED ANALYSES (2015), https://www.whitehouse.gov/omb/circulars_a094/a94_appx-c [https://perma.cc/LM5V-9JLC].

53. Present value is future value divided by $(1+$ the discount rate) raised to the exponential power of the number of periods. 
Obviously, the choice of discount rate is consequential. Start-up corporations that use a discount rate in the range of $50 \%-70 \%$ value the next generation of human beings as essentially worthless. Such an approach obviously is problematic, particularly for those who favor the use of a relatively low (or zero) social discount rate.

Overall, the financial aspects of corporate decisions that affect human life can be complex. Standard financial approaches such as NPV can lead corporations to arrive at a relatively low present value for future costs in terms of human life because of high discount rates. However, it does not follow from these difficulties that corporations should ignore these costs. For example, IKEA might not have considered the potential effects of the designs of its chests and drawers on children, or it might have estimated that its designs would cause, on average, a specified number of deaths and, nevertheless, determined that it would be worth the costs to manufacture and sell the chests and drawers.

My point here is that there are financial methodologies for corporations to use to calculate the present value of estimated future costs in terms of human life, should they choose to use them. Social policy should encourage corporations to use appropriate discount rates in these decisions. Accordingly, the next question is whether and how corporate law should seek to influence corporate decisions that affect human life.

\section{B. Legal Aspects}

In general, from the perspective of corporate law and governance, a decision that involves profit-life tradeoffs will be insulated from judicial review based on the business judgment rule. ${ }^{54}$ Directors generally have wide discretion in making corporate decisions, even when such decisions result in loss or failure. ${ }^{55}$ Absent a violation of fiduciary duty, such as a breach of the duty of loyalty, the business judgment rule would apply and there would be no basis for questioning a corporation's NPV calculations. ${ }^{56}$

In terms of the above example, there would not be a basis in corporate law for scrutinizing decisions by Company A or Company B, whether they decided to undertake the project or not. Moreover, there are no legal rules governing a corporation's use of discount rates. Directors and officers can

54. See Lori McMillan, The Business Judgment Rule as an Immunity Doctrine, 4 WM. \& MARY Bus. L. REV. 521, 524 (2013).

55. For simplicity, I have assumed that the decision in this example was informed, disinterested, and independent, and served a rational business purpose. See PALMITER \& PARTNOY, supra note 4, at 38. To the extent it did not, corporate law already provides a mechanism for challenging such a decision. See id. at chs. 18-19.

56. See Stephen M. Bainbridge, The Business Judgment Rule as Abstention Doctrine, 57 VAND. L. REV. 83, 94-95 (2004). 
make decisions and engage in oversight that puts human lives at risk, largely without a challenge related to corporate law.

The question I want to raise is whether corporate law might apply different standards to corporate decisions that involve risk to human life. As noted above, from a regulatory and tort liability perspective, there appears to be some consensus - though controversial - as to the valuation of human life, with current published averages of approximately $\$ 10$ million per life. Corporations might arrive at estimates that vary substantially from $\$ 10$ million, though that seems unlikely. Moreover, as noted above, the financial variable that matters more significantly to present value calculations is the discount rate. Even if corporate directors and officers determined that human life was worth more or less than $\$ 10$ million, their choice of discount rate likely would overshadow their valuation determination. Accordingly, the more important and more highly variable financial determinant, with respect to decisions that impact future human life, is the discount rate.

Although there is a strong rationale for deference when judges assess business decisions and oversight after the fact, the deference rationale is weaker with respect to determinations of discount rates used with respect to future human life. First, many judges, particularly in Delaware, have demonstrated expertise with respect to discount rates in a range of valuation dispute contexts. Although judges might rightly have concerns about judicial second-guessing in the business context generally, the assessment of discount rates is arguably different. Judges frequently include detailed descriptions of financial risk and valuation issues in opinions, sometimes including painstaking scrutiny of discounted cash flow analyses that involve the assessment of discount rates. ${ }^{57}$ Judges are arguably better equipped to assess the use of discount rates than they are other general business issues, and perhaps they are at least as well equipped to consider discount rates as they are conflicts of interest, where the law already provides for heightened judicial scrutiny.

Moreover, corporate law's deferential approach to the use of discount rates is arguably inconsistent with maximizing social wealth. To the extent corporate directors and officers are using discount rates that are too high, society would benefit from judicial scrutiny of such use. Suppose the optimal social discount rates for decisions that put future human life at

57. For example, in two recent cases, In re: Appraisal of Dell Inc. and In re ISN Software Corp. Appraisal Litigation, the Delaware courts demonstrated a capacity to engage in a sophisticated critique of expert valuations and make independent financial assessments using discounted cash flow analyses. See In re: Appraisal of Dell Inc., 143 A.3d 20 (Del. Ch. 2016) (Vice Chancellor Laster independently deriving fair value of Dell using a discounted cash flow analysis); In re ISN Software Corp. Appraisal Litigation, No. 8388-VCG, 2016 WL 4275388 (Del. Ch. Aug. 11, 2016) (Vice Chancellor Glasscock reaching an independent discounted cash flow valuation). 
risk are low, or even zero, reflecting a relatively high value of future generations. In the above example, if we were to use the social discount rate instead of Company B's discount rate, we would determine that, from society's perspective overall, Company B would be engaging in a project that would destroy social value. For corporations that use a higher discount rate, corporate decisions impose an externality cost on society. ${ }^{58}$

Accordingly, there is an argument that corporations should not only take into account the risks to human life but also should use a social discount rate, not their own discount rate, when doing so. To the extent corporate law or governance is relevant to such decisions, it could encourage corporations to consider an appropriate social discount rate.

In practice, present value calculations based on social discount rates would be challenging. Accordingly, one alternative role for corporate law and governance policy might be simply to "nudge" directors and officers away from decisions that most obviously would have a negative NPV, assuming it were possible to make these calculations based on an appropriate social discount rate. One way of achieving such a result might be simply to have corporate directors and officers explicitly address risk to human life and consider the various possible calculations, even while recognizing their imprecision. For example, the board of Company A might adopt a risk assessment policy stating that it would choose not to engage in projects that placed human life at "substantial" risk. The board of Company B might recognize that projects putting human life at substantial risk should not be considered using the same rubric as other projects; instead, managers would endeavor to be more careful about substantial risk to human life, consistent with the idea that they should apply a lower discount rate to such projects.

It is important to note that the factors governing corporations' determinations with respect to their decisions that pose risk to human life differ from the factors that underlie discount rates more generally. These differences vary depending on whether one is considering short-term or long-term discount rates. To the extent corporations' discount rates derive from government discount rates, they are based on factors that should not necessarily be relevant to corporate decisions that involve risk to human life. These distinctions are fundamental and are worth considering briefly.

First, with respect to the short-term end of the government yield curve, risk-free discount rates are largely determined by Federal Reserve (Fed) policy. ${ }^{59}$ Fed policy is based on macroeconomic factors, not risk to

58. See Mark C. Freeman, Reconciling the Term Structures of Corporate and Social Discount Rates (Feb. 2, 2015) (unpublished manuscript).

59. Michael Dorff raised an interesting question at Berle VIII about negative interest rates. Presumably, though strangely, in a negative interest rate regime, corporations would value future 
human life. ${ }^{60}$ Nevertheless, Fed policy impacts corporate decisions with respect to risk to human life. Recent quantitative easing policies have had the effect of lowering rates and therefore privileged future human lives. Should corporations follow the Fed's determinations and apply a low discount rate to lives it might put at risk in one year? Alternatively, if the Fed raises rates, corporations would apply a higher discount rate and therefore value future lives less.

Conversely, should the Fed take into account the effect of its interest-rate decisions on corporate decisions that put future human lives at risk? In other words, should the Fed, in addition to thinking about the impact of its interest-rate decisions on the economy, also be thinking about the fact that if it raises rates, it might lower the present value cost of human lives from the perspective of some corporations, and thereby encourage corporate decisions that put those lives at risk and potentially increase the number of people that die as a result of those decisions? A Fed rate hike might kill people.

Longer-term interest rates generate other, even more difficult issues. Determinants of the long-term government yield curve are essentially the productive capacity of the economy, productivity growth, and inflationary expectations. ${ }^{61}$ These macroeconomic factors are not factors that corporations directly consider when making decisions about future risk to human life, though they might affect those decisions. Should more productive economies, which have higher real discount rates, value human lives less? What about countries with higher expectations about inflation, which have higher nominal discount rates? Corporations operating in these countries might use higher discount rates (corporate cost of capital typically is a spread to the risk-free rate), and therefore discount the risk of loss of human life more. ${ }^{62}$

In sum, although the business judgment rule generally protects corporate decision-making from judicial review, there are some reasons to treat corporate decisions that put human life at risk differently. First, NPV

human lives more. Negative interest rates are an interesting phenomenon, but seem unlikely to persist, particularly with respect to long-term interest rates.

60. Federal Reserve Bank of San Francisco, U.S. Monetary Policy: An Introduction, Fed. RES. BANK S.F.: ECONOMIC LETTER, Jan. 1, 1999, http://www.frbsf.org/economicresearch/publications/ economic-letter/1999/january/us-monetary-policy-an-introduction/\#subhead3 [https://perma.cc/ N4WT-8CK5].

61. Tao Wu, What Makes the Yield Curve Move?, FED. RES. BANK S.F.: ECONOMIC LETTER, June 6, 2003, http://www.frbsf.org/economic-research/publications/economic-letter/2003/june/whatmakes-the-yield-curve-move/ [https://perma.cc/B6XT-HWPQ].

62. For example, the 10-year government bond yield in Brazil as of October 2016 was 11.32\%, at a time when 10-year government bond yields in many other countries, including the U.S., were below 2\%. See BLOOMBERG BARCLAYS INDICES, http://www.bloomberg.com/markets/rates-bonds [https://perma.cc/RLX6-EL69]. 
analyses of corporate decisions that involve risk to human life are fraught with difficulty. Such decisions necessarily involve an externality cost to society that standard corporate decision making approaches will not take into account. Even directors and officers who are informed, disinterested, and independent are likely to consider risk to human life from a perspective that will not internalize the social costs of risk to human life.

One important point to note is that corporations today already confront the above problems. My point here is that corporate law and governance could help improve policy by encouraging decisions that take into account social costs. Judges might scrutinize corporate decisions that otherwise would be protected by the business judgment rule if those decisions involved significant risk to human life, unless the decision-makers reasonably considered such risks. In other words, there could be a separate category of intermediate scrutiny of corporate decision-making that involves significant risk to human life. ${ }^{63}$ As an alternative to judicial implementation of this approach, state legislatures could amend their corporate statutes to provide for exculpation of directors for breaches of fiduciary duty that result in the loss of human life only if the board previously had "reasonably considered potential risks to human life." As a preliminary step to such changes, the statutes for benefit corporations might first be amended to add such a provision.

Finally, an alternative to judicial or legislative solutions is private ordering. Corporations could adopt charter or bylaw amendments, or other corporate policies, that address risk to human life. Risk management committees could amend their charters to add risk to human life as an explicit consideration. Directors and officers might adopt a practice of taking a pause to consider risk to human life before making important decisions, in the same ways doctors and nurses pause before undertaking medical procedures that put human lives at risk. ${ }^{64}$

One way to encourage private ordering solutions would be "shield" laws designed to protect the details of corporate decision-making with respect to risk to human life from scrutiny by regulators and tort litigants. Such laws might encourage directors and officers to develop a framework for considering more explicitly the various considerations related to the risk to human life posed by the corporation. Without such "shield" laws,

63. In other contexts, Delaware judges have implemented various degrees of scrutiny for corporate decisions that they perceive as involving increased risks. See Kahn v. M\&F Worldwide Corp., 88 A.3d 635, 644 (Del. 2014) (applying business judgment standard when a going private transaction is approved by a special committee of independent directors and a majority of minority shareholders); Unocal Corp. v. Mesa Petroleum Co., 493 A.2d 946 (Del. 1985) (applying enhanced scrutiny standard to merger review). (2009).

64. See generally Atul Gawande, The Checklist MANifesto: How To Get Things Right 
directors and officers likely would be reluctant to consider explicitly a particular value associated with human life (e.g., \$10 million) or a particular discount rate. Corporate actors would be especially reluctant to estimate the number of lives that likely would be impacted by a decision. And yet it is precisely such estimates, and consideration of variables - including discount rates - that are necessary if corporations are to make more thoughtful decisions about how much they are putting future human lives at risk.

\section{CORPORATE OVERSIGHT AND HUMAN LIFE}

The question I want to raise next is whether corporate oversight should be treated differently when it involves risk to human life. Put simply, should the concept of risk management explicitly include the risk of the corporation killing people?

The distinction between corporate decisions and corporate oversight is important. ${ }^{65}$ Although much of the above discussion about corporate decisions and risk to human life also applies to corporate oversight, corporate oversight is a jurisprudentially distinct area that warrants special attention. In discussing and framing fiduciary duties, courts increasingly distinguish between the roles corporate managers play when making decisions about corporate action and the roles they play when engaging in oversight. ${ }^{66}$

The oversight function of corporations has become especially important in recent years, especially for large public corporations. Of course, corporate directors and officers do not oversee every aspect of a corporation's business. Still, they have oversight responsibilities, and the role of directors and officers in "risk management" is becoming more important. Corporations increasingly have risk management committees and employ chief risk officers. Risk management and compliance are growing areas of corporate governance. ${ }^{67}$

Although public corporations in particular engage in oversight and risk management, corporate law limits private rights of action for alleged oversight violations. ${ }^{68}$ In the past, a few courts imposed higher duties for

65. See, e.g., MOdEL Bus. CORP. ACT $§ 8.31$ (2010) (AM. BAR Ass’N) (contrasting the decisionmaking and oversight functions of directors).

66. PALMITER \& PARTNOY, supra note 4, at 521-23 (describing different analytic framework for corporate decisions versus oversight).

67. For example, New York University School of Law has a program on corporate compliance and enforcement that engages a wide range of issues, scholars, practitioners, and students. See Program on Corporate Compliance and Enforcement, NYU LAw, http://www.law.nyu.edu/ corporatecompliance [https://perma.cc/NX4J-QP66].

68. See In re Caremark International Inc. Derivative Litigation, 698 A.2d 959 (Del. Ch. 1996); PALMITER \& PARTNOY, supra note 4, at ch. 16. 
certain kinds of business areas related to risk management, including some cases that imposed higher duties on directors with respect to the management of financial risk. ${ }^{69}$ Federal securities disclosure rules also are consistent with the notion that oversight of financial risk is particularly important. $^{70}$

One reason financial risk might justifiably be subject to increased oversight is the danger that corporate employees will undertake substantial long-term risks that imperil the firm. For example, a trader at a bank might sell long-dated options. A manager of a corporation with exposure to commodity prices might take positions that expose the corporation to undue risk. One goal of oversight is to address corporate agency, transaction, and information costs. To the extent corporations do not internalize such costs, they can be borne by future shareholders and stakeholders or-as in the recent financial crisis-by taxpayers and society overall. Such oversight can be through private ordering and corporate governance or through regulation, such as required disclosure and other rules.

The oversight function of public corporations is paradoxical. Although oversight failures can pose existential risks, the courts are quite deferential to a range of directorial approaches to oversight. For example, directors of Delaware corporations who exercise their oversight responsibilities in "good faith" generally do not face personal liability for monetary damages in actions involving allegations of a breach of fiduciary duty. ${ }^{71}$ Directors also have the right to rely on others, including employees, legal counsel, and outside experts. ${ }^{72}$

Consider, for example, the autonomous car mentioned in the introduction. Pedestrians in six Amazon Mechanical Turk studies recently said they approved of vehicles that were programmed to sacrifice their passengers for the greater good and would like other customers to buy such

69. See Hoye v. Meek, 795 F.2d 893 (10th Cir. 1986) (finding director liability for delegating authority and not adequately supervising investments subject to interest rate risk); Brane v. Roth, 590 N.E.2d 587, 589 (Ind. Ct. App. 1992) (describing lower court finding that directors breached their fiduciary duties by "retaining a manager inexperienced in hedging; failing to maintain reasonable supervision over him; and failing to attain knowledge of the basic fundamentals of hedging to be able to direct the hedging activities and supervise the manager properly"). Arguably, the Delaware courts have moved in the opposite direction, showing deference in cases addressing financial risk, even with respect to bankers' oversight failures during the financial crisis. See, e.g., In re Citigroup Inc. Shareholders Derivative Litigation, 964 A.2d 106 (Del. Ch. 2009) (no liability for failing to supervise Citigroup's exposure to subprime mortgage-related assets).

70. Nevertheless, there is evidence that securities are not effective in these areas. See FrANK Partnoy, Infectious Greed: How Deceit and Risk CorRuPted the Financial Markets (2009); Partnoy \& Eisinger, supra note 12.

71. See Del. Code AnN. tit. 8, § 102(b)(7) (West 2015); Stone v. Ritter, 911 A.2d 362 (Del. 2006).

72. See PALMiter \& PARTNOY, supra note 4, at 584-85. 
"utilitarian" vehicles, but also said that they would themselves prefer to ride in vehicles that protect passengers at all costs. ${ }^{73}$

Given these consumer preferences, how should the board of an autonomous car manufacturer approach the oversight question? Current judicial deference recognizes that overseeing these kinds of questions is difficult. Directors are required to attend meetings and participate in governance, but generally can rely on management to provide relevant information. ${ }^{74}$ However, if directors become aware over time that they need additional information, they are charged with the responsibility to request it. ${ }^{75}$

Moreover, the focus of risk management oversight is often on considerations of regulatory violations and tort liability. The Caremark decision that governs board oversight involved a criminal indictment, a guilty plea, and corporate reimbursements to various private and public parties of approximately $\$ 250$ million. ${ }^{76}$ Likewise, Stone v. Ritter involved both criminal and civil liability for compliance violations. ${ }^{77}$ Well-advised directors understand from these cases that the focus is on whether they utterly failed to implement any reporting or information system or controls, or, having implemented such a system or controls, consciously failed to monitor or oversee its operations thus disabling themselves from being informed of risks or problems requiring their attention. ${ }^{78}$ These are low bars. It would be difficult to hold directors of an autonomous car company responsible for algorithms that resulted in more deaths.

There are drawbacks to having the focus of director oversight be on regulatory and tort costs. One way to think about director oversight and risk management is that directors are setting a policy that optimizes the corporation's approach to risk. Given the large number of corporate violations of law, this calculus obviously does not involve a zero tolerance approach, or an expectation of zero liability costs. Instead, one rational oversight approach is to minimize the sum of compliance costs and liability costs. Thus, directors look to regulatory and tort liability to assist with oversight. If the regulatory and tort regimes are well functioning, one might argue that directors should simply maximize shareholder value,

73. Jean-Francois Bonnefon, Azim Shariff \& Iyad Rahwan, The Social Dilemma of Autonomous Vehicles, 352 SCIENCE 1573, 1573 (2016).

74. See Am. Bar Ass'n, Corporate Director's Guidebook, 33 Bus. LAw. 1591, 1602 (1978).

75. Id. (describing adequate information and reliance on others).

76. See In re Caremark International Inc. Derivative Litigation, 698 A.2d 959 (Del. Ch. 1996).

77. See Stone v. Ritter, 911 A.2d 362 (Del. 2006).

78. See id. 
subject to regulatory and tort costs. ${ }^{79}$ But, that policy depends on well-functioning regulatory and tort liability regimes.

Do regulatory and tort regimes lead corporations to internalize the social costs of their oversight failures when there is risk to human life? There are many reasons to conclude they do not. Because regulatory intervention and tort litigation are costly, they are likely to result in lower nominal private costs for corporations than the social costs borne by society with respect to corporate decisions that result in death. Some cases are not brought, some lose, and some settle for small amounts. Corporate actors that internalize only future litigation costs might under weigh human life in their cost-benefit analysis. (Alternatively, if regulatory and tort costs are too high, corporations might over weigh human life and avoid projects that otherwise would generate value for society.)

In addition, because regulatory enforcement and tort litigation lead to private costs of deaths being borne later in time than social costs of deaths, the present value of private costs typically would be lower than present value of social costs. Because private discount rates generally are higher than social discount rates, private costs are thus likely to be lower than social costs. ${ }^{80}$ As previously noted, the relationship between private and social discount rates is complicated. ${ }^{81}$ Moreover, it is difficult to determine whether one should incorporate risk by adjusting the cash flow stream, the discount rate, or both. ${ }^{82}$

In general, oversight based on future expected costs from the regulatory and tort regimes is unlikely to lead corporations to internalize social costs in an optimal way. Agency costs can lead corporations not to internalize the difference between social costs and private costs. Likewise, transaction and information costs can be high. The very market failures that create a need for regulation and tort liability also create difficulties in using the expected cost of those regimes as proxies to internalize social costs. Some corporations might try to internalize the effects of their actions

79. Milton Friedman, The Social Responsibility of Business is to Increase its Profits, N.Y. TIMES, Sept. 13, 1970 (Magazine).

80. See EPA, Guidelines for Preparing ECONOMiC ANALySEs 6-1, 6-120 (Dec. 2010), https://yosemite.epa.gov/ee/epa/eerm.nsf/vwAN/EE-0568-06.pdf/\$file/EE-0568-06.pdf [https://perma.cc/3VSD-DQX9]; Mark C. Freeman \& Ben Groom, Positively Gamma Discounting: Combining the Opinions of Experts on the Social Discount Rate, 125 ECON. J. 1015 (2015); Freeman, supra note 58.

81. Michael Klausner has argued that the determinants of financial discount rates are not useful when considering the intergenerational tradeoffs that are related to social discount rates. See Klausner, supra note 23 .

82. See Peter S. Spiro, The Social Discount Rate for Provincial Government Investment Projects, in Discount Rates for the Evaluation of Public Private Partnerships (D. Burgess \& G. P. Jenkins eds., 2010), http://www.peterspiro.com/Social_Discount_Rate.pdf [https://perma.cc/FD99S3AJ]. 
on human life through oversight, but corporations that try to do so will confront these costs.

Of course, one solution would be to improve regulation and tort litigation. Perhaps government entities could more precisely value the potential risk to human life, discern appropriate discount rates, and then impose costs on corporate conduct, which over time would lead directors to adopt optimal risk management policies. Regulatory and tort reform might lead corporations to internalize the risks posed to human life by adjusting outlier awards as well as pre- and post-judgment interest. They might be designed so that costs would increase at rates that precisely match the social discount rate (or, for corporations that discount at a higher rate, that higher rate). ${ }^{83}$ But those reforms are difficult and unlikely.

My suggestions are simpler. To the extent corporate directors recognize the problems associated with their oversight function, they might adopt policies designed to emphasize avoiding risk to human life. For example, boards of autonomous car manufacturers could warn employees not to weigh protecting passengers significantly more than protecting people in other cars or pedestrians. More generally, boards could emphasize the importance of human life in their approach to oversight. Such an approach might include not only third parties who might be killed but also current employees. Corporations (and perhaps law firms?) that ask employees to work long hours might take into account not only quality of life and productivity ${ }^{84}$ but also the increased likelihood of death.

Boards might vary their oversight approach depending on the riskiness of the corporation, and its cost of capital, in the same way as discussed above with respect to decision-making. For example, consider the board of Google overseeing autonomous cars versus a start-up corporation's board overseeing the same risks. Google's cost of capital is likely to be substantially lower than that of a start-up, which suggests that a start-up might have substantially lower incentives to engage in rigorous oversight. Or consider an established pharmaceutical corporation, such as Pfizer, versus a smaller company. A smaller corporation with a higher cost of capital might have greater incentives to provide lethal injection drugs, because it might (wrongly) use a higher discount rate and therefore face a future risk to human life that was lower in present value terms. ${ }^{85}$ As noted

83. I am grateful to Ed Rock and Kevin Davis for mentioning this issue.

84. See Tony Schwartz, Escalating Demands at Work Hurt Employees and Companies, N.Y. TiMES (June 5, 2015), http://www.nytimes.com/2015/06/06/business/dealbook/excessive-demandsat-work-create-a-humanitarian-crisis.html?_r $=0$.

85. In fact, some states have considered turning to smaller compound pharmacies to provide lethal drugs; these companies would have a higher cost of capital than prior providers. See Frank Stoltze, California Considers Making its Own Lethal Drugs for the Death Penalty, 89.3 KPCC (May 
above, corporations that discount risk to human life at a high rate are imposing an externality cost on society.

Boards also could recognize the importance of agency costs in their oversight of risks to human life. Corporations with a large number of employees pose greater oversight challenges to the extent lower level employees do not internalize the costs associated with risks to human life. Consider the example of a car manufacturer deciding whether to spend an extra few dollars to purchase a more expensive airbag. A mid-level manager charged with making decisions about airbags might not value human lives as much as the corporation - or society - and might apply a much higher discount rate. One way to approach the agency-cost problem would be to encourage a culture that emphasizes the importance of avoiding risk to human life. The board and senior management might adopt such a policy.

Finally, boards might move beyond cost-benefit analysis in their oversight function and decide to value human life highly, even if that value cannot be quantified. Returning to the example of car manufacturers, a board might decide that avoiding risk to human life is a paramount objective and, accordingly, articulate that managers should make every effort to design and manufacture cars that are as safe as is reasonably possible, even if those efforts result in higher costs.

At some point, cost-benefit analysis becomes contrary to a corporation's - or society's - shared values. For example, the cost-benefit analysis of the externality costs of smokers to society would include the positive values society would accrue from the cost savings associated with smokers' premature deaths. ${ }^{86}$ Such calculations have offended many people in the past, and it is unlikely that a corporate board today would argue in favor of a decision because it generated positive externalities benefits from premature deaths. And yet if corporations do not explicitly consider risk to human life, they might be incentivizing actions that lead to death.

17, 2016), http://www.scpr.org/news/2016/05/17/60667/california-considers-making-its-own-lethaldrugs-f/ [https://perma.cc/RV8M-KXM6]. For a valuation/cost of capital for compound pharmaceuticals, see also IBISWORLD, REPORT OD5706 COMPOUNDING PHARMACIES IN THE US (2015), http://truenaturepharma.com/wp-content/uploads/2016/01/Compounding-PharmaciesIndustry-Report.pdf [https://perma.cc/35ZZ-7VTT]; Ed Webman, Use Your Pharmacy's Valuation as a Management Tool, AMERICA's PHARMACIST 26 (May 2016), http://www.ncpa.co/pdf/webmanpharmacy-valuation-article.pdf [https://perma.cc/FQK4-QGPY] (assessing the valuation and cost of capital for compound pharmaceuticals).

86. See W. Kip Viscusi, Cigarette Taxation and the Social Consequences of Smoking 33 (Nat'1 Bureau of Econ. Research, Working Paper 4891, 1994), http://www.nber.org/papers/w4891.pdf ("Taken at face value, these estimates indicate that if one were to set the Pigouvian tax amount based on the 3 percent discount rate results, that cigarette smoking should be subsidized rather than taxed."). 
At least initially, the above suggestions could be adopted by just a few corporate boards on a pilot basis. For example, benefit corporations are positioned to embrace the expansion of the oversight function to explicitly address risk to human life. Of traditional for-profit corporations, those that emphasize human life might be among the early adopters; perhaps Chick-fil-A, a company that emphasizes human life in its mission, might implement a heightened approach to oversight as it relates to human life at the board level. Expanded oversight would be consistent with some scholarly views that corporations are not merely economic entities. ${ }^{87}$

Finally, Charles O'Kelley raised a crucially important question during the discussion at the Berle Symposium about oversight, corporations, and human life. ${ }^{88}$ What should we do about the risks that corporations will engage in practices that kill, not only some people, but the entire human species? Even the most ardent advocates of shareholder primacy would support policy adjustments that would prevent corporations from killing all humans (which would include shareholders). Every corporation should consider such oversight.

One cautionary note: I want to be clear that my analysis of corporations and human life is not necessarily inconsistent with concerns that corporations are too risk averse and that corporate law and governance should serve primarily to encourage innovation and risk-taking. It is worth pausing for a moment to respond to a question raised by Professor David Musto at Berle VIII about whether, in fact, corporate actors today are too worried about killing humans and therefore are not engaging in risky projects that would be beneficial for society overall. ${ }^{89}$ Essentially, his question was whether my assumptions about how corporate actors assess human risk has the wrong arithmetical sign.

I responded then, and I continue to respond now, that it nevertheless is interesting and important to consider the question of corporations and human life. If the academic consensus is that corporations are not putting enough future human lives at risk (a position I doubt would reach consensus), then corporate law and policy could respond to that deficiency by insulating corporate actors from liability and incentivizing oversight policies that encourage such risk-taking. In other words, scholars who share the views Professor Musto raised might simply reverse this Article's

87. See David Ciepley, Beyond Public and Private: Toward a Political Theory of the Corporation, 107 AM. POL. SCI. REV. 139, 140 (2013).

88. See Charles O'Kelley, The Corporation and Human Life Q \& A, Seattle University School of Law Symposium: Berle VIII: Benefit Corporations and the Firm Commitment Universe (June 27, 2016).

89. See David Musto, The Corporation and Human Life Q \& A, Seattle University School of Law Symposium: Berle VIII: Benefit Corporations and the Firm Commitment Universe (June 27, 2016). 
policy prescriptions and encourage legislators to add additional protections to corporate law with respect to decisions and oversight that affect human life. In any event, the appropriate response to questions about corporations and human life is not to do nothing. This would only be appropriate if both sides are wrong, and corporations miraculously are precisely calibrating their decisions and oversight to the risks associated with future loss of human life.

\section{CONCLUSION}

Human beings make judgments about the impact of our decisions and actions on human life. We typically try not to kill others, and we can suffer consequences when we do. Decisions about human life are difficult and sensitive, but we do not avoid them. We often, or at least sometimes, think explicitly about risk to human life.

My point here is that the same kinds of difficult issues that arise for human persons also arise for corporate persons. Are corporations adequately factoring into their decisions and oversight the costs and benefits associated with saving human lives or causing deaths? Are they appropriately considering factors beyond cost-benefit analysis?

This Article has explored some of the ways corporations that use traditional financial discounting concepts should amend their approaches when human life is involved. At a minimum, corporations should explicitly consider how their decisions and oversight might impact human life; they should not ignore such impacts. Nor should they simplistically monetize risk to human life based on expected tort and regulatory liability discounted at their applicable cost of capital. A better approach would be to assess the impact on human life explicitly, make judgments about how many lives likely would be affected, and when, and then use a low social discount rate to convert that future value into today's terms.

But is there an even better approach? Although tort and regulatory systems convert the value of human lives into a number, as do life insurance markets, such conversions lack precision, can be arbitrary, and raise difficult moral questions. Michael Klausner has suggested, in the nonprofit charitable foundation context, that the concept of financial discounting is inapplicable when human lives are involved. His argument is that foundations should abandon financial valuation and discounting and instead should turn to questions about intergenerational equity and tradeoffs that maximize social welfare across generations. ${ }^{90}$ For example, one rationale for charity to be provided sooner rather than later is that earlier grants will be more cost effective, as in environmental efforts today

90. Klausner, supra note 23 , at 56-58. 
versus in the future. Another rationale is that future generations might be sufficiently better off such that current generations should be preferred, not because of financial discounting, but because resources should go to humans who are worse off instead of those who are better off. One additional profound reason not to value human lives far into the future is the fact that the world might not exist then.

Corporate directors and officers might consider such larger philosophical questions, instead of merely discounting future expected costs. The two-step process of estimating future costs in terms of human life and then discounting is likely to be imprecise. Would thinking about cost effectiveness, economic growth, intergenerational equity, and the potential end of the world be any less precise? Corporations necessarily will be involved in decisions and oversight that impact human life, so it is worth confronting how their leaders should think about such questions. Corporations that do not consider such impacts, or that use a high discount rate in assessing risk to human life, are imposing an unwarranted externality on society.

As noted above, some corporations, such as Hobby Lobby and Chick-Fil-A, already embrace corporate purposes related to human life. Moreover, state statutes provide for nonprofit corporations and benefit corporations, many of whose charters articulate values that include the value of human life, with hospitals being the obvious example. There are religious corporations, just as there were hundreds of years ago. ${ }^{91}$ But increasingly, some of thorniest issues in corporate law are posed by for-profit corporations whose constituents profess to care about human life.

What would it mean for a for-profit corporation to care about human life? The Hobby Lobby law professors' brief argued that there should be a veil between shareholders and corporations; corporations should not be assumed to have adopted the political views of their shareholders. ${ }^{92} \mathrm{~A}$ corporation does not become pro-life simply because some, or even all, of its shareholders hold those views.

But what about the idea that corporations should consider human life, not in the narrow political sense, but in a more general moral and economic

91. Moreover, state statutes, such as Section 9130 of the California Corporations Code, permit a corporation to be designed as a "religious corporation." Such a "religious corporation" must include a statement in its articles that: "This corporation is a religious corporation and is not organized for the private gain of any person. It is organized under the Nonprofit Religious Corporation Law (primarily or exclusively [insert one or both]) for religious purposes." CAL. CORP. CODE $§ 9130$ (2013).

92. See Brief for Corporate and Criminal Law Professors at *2 as Amici Curiae Supporting Petitioners, Burwell v. Hobby Lobby Stores, Inc., 134 S.Ct. 2751 (2014) (No. 13-354 and 13-356), 2014 WL 333889. 
sense? Such "pro-life" values would not necessarily emanate from shareholders, but perhaps from the corporation itself.

As Colin Mayer suggested at the symposium, it is important to consider which of the corporate constituents - shareholders, directors, officers, customers, employees, government, or society generally-is making a particular decision or engaging in oversight, or would benefit (or be harmed by) a decision. ${ }^{93}$ With respect to this Article's topic of human life, the answer to his question is clear: directors and senior officers are the ones responsible. The trade-offs associated with corporations and human life typically run from decisions and oversight by directors or officers to harms to customers, employees, and society. The most important constituents - future third-party victims of corporate decisions and oversight - are poorly represented in any relevant corporate decisions and oversight and are unlikely to be involved in the corporate contract in any meaningful way. Accordingly, my focus here has been on the actions and views of directors and officers, and the impact of their actions on these third-party victims.

Corporate directors and officers are the corporate actors best positioned to think carefully about the impact of their decisions and oversight on human life. This Article is intended to start the conversation about them doing so.

93. See Colin Mayer, The Corporation and Human Life Q \& A, Seattle University School of Law Symposium: Berle VIII: Benefit Corporations and the Firm Commitment Universe (June 27, 2016). 